\title{
PENGARUH TINGKAT SUKU BUNGA SBI TERHADAP NILAI TUKAR RUPIAH STUDI PADA BANK INDONESIA
}

\author{
Melinda Puspita Ayu Kirana \\ Mahasiswa Prodi Pendidikan Ekonomi \\ melindaayu18@gmail.com
}

\begin{abstract}
This study describes the influence of SBI interest rate on the rupiah at Bank Indonesia studies. The method in this research is descriptive method with quantitative approach. Determination of the sample is based on time series data 2009-2015 period by using saturation sampling methods as many as 84 samples. This research was conducted at Bank Indonesia has the sole purpose of achieving and maintaining stability in the rupiah. This study uses simple linear regression analysis which includes the classical assumption and hypothesis testing in the form of the coefficient of determination $\left(r^{2}\right)$ and the partial test $(t$ test). The results showed that the interest rate significantly influence the exchange rate. This is shown by the results of the t test $T_{-}$hitung amounted to 9.745, while $T_{-}$(table) amounted to 1,989. This means $T_{-}$(count) $\geq T_{-}$tabel $(9.745 \geq 1.989)$ it can be concluded that the null hypothesis is rejected and the alternative hypothesis is accepted.
\end{abstract}

Keywords: SBI Interest Rate, Exchange Rate

\begin{abstract}
Abstrak
Penelitian ini memaparkan pengaruh tingkat suku bunga SBI terhadap nilai tukar rupiah pada studi Bank Indonesia. Metode dalam penelitian ini adalah metode deskriptif dengan menggunakan pendekatan kuantitatif. Penentuan sampel berdasarkan data time series periode 2009-2015 dengan menggunakan metode sampling jenuh yaitu sebanyak 84 sampel. Penelitian ini dilakukan pada Bank Indonesia memiliki tujuan tunggal yakni mencapai dan memelihara kestabilan nilai Rupiah. Penelitian ini menggunakan metode analisis regresi linier sederhana yang memuat uji asumsi klasik dan pengujian hipotesis yang berupa koefisien determinasi $\left(\mathrm{r}^{2}\right)$ serta uji parsial (uji $\mathrm{t}$ ). Hasil penelitian menunjukkan bahwa tingkat suku bunga berpengaruh signifikan terhadap nilai tukar rupiah. Hal ini ditunjukkan berdasarkan hasil uji t yakni $T_{\text {hitung }}$ sebesar 9,745, sedangkan $T_{\text {tabel }}$ sebesar 1,989. Hal ini berarti $T_{\text {hitung }} \geq T_{\text {tabel }}(9,745 \geq 1,989)$ maka dapat disimpulkan bahwa hipotesis nol ditolak dan hipotesis alternatif diterima.
\end{abstract}

Kata Kunci: Tingkat Suku Bunga SBI, Nilai Tukar Rupiah

\section{PENDAHULUAN}

Perdagangan internasional adalah jembatan bagi setiap negara untuk bekerja sama guna mendapatkan keuntungan bersama. Dengan adanya perdagangan internasional, setiap negara dapat menjalin persahabatan antar negara. Perdagangan antar negara (trade) mengakibatkan terjadinya pertukaran mata uang suatu negara dengan negara lainnya. Oleh karena itu, guna memperlancar transaksi perdagangan internasional maka ditetapkanlah mata uang yang telah disepakati oleh suatu negara. Mata uang yang digunakan ialah mata uang Amerika Serikat yaitu Dollar Amerika (US/\$) karena Dollar Amerika merupakan salah satu mata 
uang yang kuat bagi negara berkembang.

Ketika rupiah terhadap dollar mulai tidak stabil, maka hal tersebut akan mengganggu aktivitas perdagangan internasional yang terjalin bagi kedua negara. "Kestabilan nilai ternyata merupakan faktor yang sangat menentukan apakah suatu mata uang bisa diterima dan berperan sebagai mata uang cadangan internasional" (Boediono, 2013: 97). Ketidakstabilan akan suatu mata uang akan berdampak langsung pada perubahan nilai tukar. "Perubahan nilai tukar ini berpengaruh langsung terhadap perkembangan harga barang dan jasa dalam negeri" (Puspitaningrum dkk, 2014: 1).

Menurunnya permintaan masyarakat terhadap mata uang rupiah dan lebih memilih mata uang asing sebagai alat pembayaran internasional pun dapat menyebabkan perubahan nilai tukar karena dengan meningkatnya mata uang asing dapat berdampak pada meningkatnya bahan baku sehingga dapat berpengaruh pada ketidakstabilan nilai tukar rupiah.

Risiko perubahan nilai tukar/kurs adalah kemungkinan kerugian bank yang timbul karena perubahan nilai tukar antara dua mata uang. Adanya perubahan nilai tukar juga berpengaruh pada apresiasi dan depresiasi mata uang. "Mata uang suatu negara dikatakan mengalami depresiasi terhadap mata uang negara lain jika mata uang suatu negara mengalami penurunan nilai, dan sebaliknya mengalami apresiasi terhadap mata uang negara lain jika mengalami kenaikan nilai" (Agus Sartono, 2003: 18). Mata uang rupiah merupakan mata uang yang mudah terdepresiasi karena perekonomian yang relatif kurang stabil.

Perubahan nilai tukar Rupiah terhadap mata uang Dollar AS dipengaruhi oleh banyak faktor. Beberapa di antaranya adalah kondisi makro ekonomi suatu negara. Tingkat suku bunga SBI merupakan salah satu faktor yang penting dalam makro ekonomi. Fluktuasi nilai tukar yang berimplikasi pada perubahan tingkat inflasi pada akhirnya mengakibatkan pula kenaikan dan penurunan suku bunga domestik. Melalui Bank Sentral (BI) yang merupakan lembaga negara yang bertujuan mengelola jumlah uang yang beredar, mengatur level suku bunga, memelihara ketersediaan kredit diharapkan dapat menjaga kestabilan nilai tukar rupiah.

Sertifikat Bank Indonesia (SBI), merupakan suatu surat berharga yang diterbitkan oleh bank Indonesia guna mengendalikan jumlah uang yang beredar. Kenaikan dan penurunan tingkat suku bunga SBI mencerminkan tingkat bunga rupiah yang berlaku di pasar.

Menurut Frederic S. Mishkin (2008: 105) perubahan dalam suku bunga domestik seringkali menjadi faktor umum yang mempengaruhi nilai tukar. Ketika suku bunga riil domestik mengalami kenaikan, maka mata uang domestik mengalami apresiasi. Sebaliknya ketika suku bunga domestik mengalami kenaikan menuju perkembangan inflasi yang diharapkan maka mata uang domestik akan terdepresiasi.

Perubahan tingkat suku bunga juga akan memberikan pengaruh terhadap aliran dana suatu negara sehingga akan berpengaruh terhadap permintaan serta penawaran nilai tukar mata uang. "Secara umum semakin rendah tingkat suku bunga maka akan semakin besar intensitas aliran dana sehingga semakin besar tingkat pertumbuhan ekonomi, dan sebaliknya apabila semakin tinggi tingkat bunga maka akan semakin rendah tingkat pertumbuhan ekonomi' (Agus Sartono, 2001: 42).

Penelitian ini dilakukan pada Bank Indonesia yang selaku bank sentral berdasarkan pasal 4 ayat 1 Undang-undang RI No. 23 Tahun 1999. Bank Indonesia merupakan lembaga negara yang independen dan memiliki satu tujuan tunggal yakni mencapai dan memelihara kestabilan nilai rupiah. 
Peneliti memilih lokasi penelitian pada Bank Indonesia karena Bank Indonesia memiliki wewenang dalam mengeluarkan kebijakan terkait mata uang guna menjaga kestabilan rupiah. Oleh sebab itu, pengamatan terhadap perubahan beberapa variabel makro ekonomi diharapkan dapat membantu dalam meramalkan nilai tukar Rupiah.

\section{Tingkat Suku Bunga SBI}

Sunariyah (2004: 80) mendefinisikan bunga merupakan suatu ukuran harga sumber daya yang digunakan oleh debitur yang dibayarkan kepada kreditur. Sedangkan menurut Sadono Sukirno (2014: 375) bahwa "pembayaran ke atas modal yang dipinjam dari pihak lain dinamakan bunga".

Tingkat suku bunga merupakan harga yang harus dibayar oleh peminjam untuk memperoleh dana dari pemberi pinjaman untuk jangka waktu yang disepakati.

Menurut Sunariyah (2004: 80-81), terdapat 4 fungsi suku bunga sebagai berikut:

1. Sebagai daya tarik bagi para penabung yang mempunyai dana lebih untuk diinvestasikan.

2. Tingkat bunga dapat digunakan sebagai alat kontrol bagi pemerintah terhadap dana langsung atau investasi pada sektor-sektor ekonomi.

3. Tingkat bunga dapat digunakan sebagai alat moneter dalam rangka mengendalikan penawaran dan permintaan uang yang beredar dalam suatu perekonomian.

4. Pemerintah dapat memanfaatkan suku bunga untuk mengontrol jumlah uang beredar. Ini berarti, pemerintah dapat mengatur sirkulasi uang dalam suatu perekonomian.

Tingkat suku bunga SBI merupakan salah satu faktor yang penting dalam makro ekonomi. Fluktuasi nilai tukar yang berimplikasi pada perubahan tingkat inflasi pada akhirnya mengakibatkan pula kenaikan dan penurunan suku bunga domestik. Melalui Bank Sentral (BI) yang merupakan lembaga negara yang bertujuan mengelola jumlah uang yang beredar, mengatur level suku bunga, memelihara ketersediaan kredit diharapkan dapat menjaga kestabilan nilai tukar rupiah.

Ketika Bank Sentral membeli atau menjual, bank sentral melakukannya dengan harga dan suku bunga yang berlaku dalam pasar uang, yang merupakan dealer sekuritas pemerintah/SBI. Selain untuk keperluan ekspansi dan kontraksi moneter, SBI dipakai pula untuk mengendalikan secara tidak langsung tingkat bunga dalam pasar uang (Jose Rizal Joesoef, 2008: 66).

Menurut Herman Darmawi (2006: 93) Sertifikat Bank Indonesia atau SBI pada prinsipnya adalah surat berharga atas unjuk dalam rupiah, yang diterbitkan dengan sistem diskonto oleh bank sentral Indonesia sebagai pengakuan utang berjangka waktu pendek. Tujuannya adalah sebagai sarana pengendalian moneter melalui operasi pasar terbuka, selain sebagai alat operasi pasar terbuka untuk mengendalikan moneter melalui lelang harian.

\section{Nilai Tukar}

Menurut M. Faisal (2001: 20) nilai tukar/kurs (exchange rate) adalah harga mata uang (yang diekspresikan) terhadap mata uang lainnya. Sedangkan menurut Martono dan Harjito (2007: 382) "Nilai tukar (kurs atau exchange rate) menunjukkan banyaknya unit mata uang yang dapat dibeli atau ditukar dengan satuan mata uang lain atau harga suatu mata uang yang dinyatakan dalam mata uang lainnya".

Selama kurs adalah angka yang mengindikasi nilai tukar mata uang domestik terhadap mata uang asing, maka kurs pada waktu tertentu bisa berubah ke arah menurun (berkurang) atau meningkat (bertambah) relatif terhadap kurs itu pada waktu sebelum- 
nya. Apabila nilai tukar mata uang domestik terhadap mata uang asing menurun (berkurang), mata uang domestik dikatakan terdepresiasi. Sebaliknya, jika nilai tukar mata uang domestik terhadap mata uang asing meningkat (betambah) mata uang domestik dikatakan terapresiasi (Jose Rizal Joesoef, 2008: 13).

"Cara penulisan harga mata uang dengan menyatakan sekian unit mata uang lokal yang diperlukan untuk mendapatkan satu unit mata uang asing dinamakan direct quotation" (Jose Rizal Joesoef, 2008: 25). Secara umum, formula penilaian kurs secara direct adalah:

\section{Direct Quotation $=$}

$\frac{\text { jumlah unit mata uang lokal }}{\text { satu unit mata uang asing }}$

Sumber : Jose Rizal Joesoef (2008: 25)

Sebaliknya, ada suatu negara yang menulis kurs dengan mengunci satu unit mata uang lokalnya yang dapat ditukar terhadap sekian unit mata uang asing dinamakan indirect quatation (Jose Rizal Joesoef, 2008: 25). Secara umum, formula penilaian kurs secara indirect adalah :

Indirect Quotation $=$

$\frac{\text { jumlah unit mata uang asing }}{\text { satu unit mata uang lokal }}$

Sumber: Joesoef(2008: 25)

Jeff Madura (2006: 220-224) mengemukakan "bahwa sistem nilai tukar dikategorikan dalam beberapa jenis berdasarkan pada seberapa kuat tingkat pengawasan pemerintah terhadap nilai tukar". Secara umum nilai tukar diklasifikasikan dalam kategori-kategori berikut:

1) Sistem nilai tukar tetap (fixed exchange rate system), dalam sistem nilai tukar tetap nilai tukar dibuat konstan ataupun hanya diperbolehkan berfluktuasi dalam kisaran yang sempit. Bila pada suatu saat nilai tukar mulai berfluktuasi terlsalu besar, maka pemerintah akan melakukan intervensi untuk menjaga agar fluktuasi tetap berada dalam kisaran yang diinginkan.

2) Sistem nilai tukar mengambang bebas (freelly floating exchange rate system), sistem nilai tukar ditentukan sepenuhnya oleh pasar tanpa adanya intervensi dari pemerintah. Pada sistem nilai tukar mengambang bebas diperbolehkan adanya fleksibilitas nilai tukar secara penuh. Nilai tukar akan disesuaikan secara terus menerus sesuai dengan kondisi penawaran dan permintaan di mata uang tersebut. Dalam sistemsistem ini perusahaan-perusahaan multinasional perlu mencurahkan sumber daya yang substansial untuk mengukur dan mengelola risiko valuta asing.

3) Sistem nilai tukar mengambang terkendali (managed floating exchange rate system) sistem nilai tukar yang ada saat ini pada bagian besar mata uang berada dia antara sistem nilai tukar tetap dan sistem nilai tukar bebas. Sistem nilai tukar ini menyerupai sistem nilai tukar mengamang bebas karena nilai tukar dibiarkan berfluktuasi setiap hari dan tidak ada batasan-batasan resmi. Tetapi, sewaktu-waktu melakukan intervensi untuk menghindari fluktuasi yang terlalu jauh dari mata uang tersebut.

4) Sistem nilai tukar terikat (peeged exchange rate), dimana mata uang lokal dari negara-negara yang menggunakan sistem nilai tukar ini dikaitkan nilainya pada sebuah valuta asing atau pada sebuah mata uang tertentu. Sehingga nilai mata uang lokal akan mengikuti 
fluktuasi dari nilai mata uang yang dijadikan ikatan tersebut.

Terdapat banyak faktor yang mempengaruhi perubahan nilai tukar mata uang. Menurut Madura (2006: 128), faktor-faktor yang dapat mempengaruhi nilai tukar di antaranya:

1. Tingkat inflasi relatif

Perubahan pada tingkat inflasi relatif dapat mempengaruhi aktivitas perdagangan internasional yang akan mempengaruhi permintaan dan penawaran mata uang dan karenanya mempengaruhi kurs nilai tukar.

2. Suku bunga relatif

Perubahan pada suku bunga relatif mempengaruhi investasi pada sekuritas asing, yang akan mempengaruhi permintaan dan penawaran mata uang dan karenanya akan mempengaruhi kurs nilai tukar.

3. Tingkat pendapatan relatif

Pendapatan mempengaruhi jumlah permintaan barang impor, maka pendapatan dapat mempengaruhi kurs mata uang.

4. Pengendalian pemerintah

Pemerintah mempengaruhi kurs keseimbangan dengan cara termasuk, (1) mengenakan batasan pada penukaran mata uang asing, (2) mengenakan batasan atas perdagangan asing, (3) mencampuri pasar mata uang asing, dan (4) mempengaruhi variabel makro.

5. Prediksi Pasar

Seperti pasar keuangan lain, pasar mata uang asing juga bereaksi terhadap berita yang memiliki dampak masa depan.

Sedangkan Afsia Murni (2006: 246)

menyebutkan kurs valuta asing dapat berubah bila terjadi:

1. Perubahan selera
2. Perubahan harga barang impor dan ekspor

3. Terjadinya inflasi

4. Perubahan suku bunga dan

5. Tingkat pengembalian investasi

\section{TINGKAT SUKU BUNGA DAN NILAI TUKAR}

Menurut Frederic S. Mishkin (2008: 105) perubahan dalam suku bunga domestik seringkali menjadi faktor umum yang mempengaruhi nilai tukar. Ketika suku bunga riil domestik mengalami kenaikan, maka mata uang domestik mengalami apresiasi. Sebaliknya ketika suku bunga domestik mengalami kenaikan menuju perkembangan inflasi yang diharapkan maka mata uang domestik akan terdepresiasi.

\section{METODE PENELITIAN}

Penelitian ini merupakan sebuah penelitian yang diperoleh dari data website Bank Indonesia (www.bi.go.id). Alasan dilakukan pada Bank Indonesia karena Bank Indonesia menyediakan data-data yang dibutuhkan dalam penelitian.

Dalam menyelesaikan penelitian ini perlu digunakan cara atau metode yang tepat dipertanggungjawabkan secara ilmiah. Penelitian ini menggunakan penelitian kuantitatif, dengan demikian "metode kuantitatif dapat diartikan sebagai metode penelitian yang berlandaskan pada filsafat positivisme, digunakan untuk meneliti pada populasi atau sampel tertentu, pengumpulan data menggunakan instrumen penelitian, analisis data bersifat kuantitatif/statistik, dengan tujuan untuk menguji hipotesis yang telah ditetapkan" (Sugiyono, 2014: 11).

Penelitian ini dilakukan pada website Bank Indonesia (www.bi.go.id). Menurut Jose Rizal Joesoef (2008: 7) bahwa Bank Indonesia selaku Bank sentral adalah lembaga negara yang bertujuan mengelola jumlah uang yang beredar, mengatur level 
suku bunga, memelihara ketersediaan kredit dan menjaga nilai tukar mata uang negara terhadap mata uang lainnya.

Penelitian ini menggunakan data sekunder. Data sekunder yang digunakan berupa time series. Data time series adalah "sebuah kumpulan observasi terhadap nilainilai sebuah variabel dari beberapa periode waktu yang berbeda" (Damodar N. Gujarati, 2010:28).

Desain penelitian yang digunakan dalam penelitian ini menggunakan hubungan kausal. Menurut (Sugiyono, 2014: 62) "hubungan kausal adalah hubungan yang bersifat sebab akibat". Dalam penelitian ini menjelaskan pengaruh kausal antara variabel melalui pengajuan hipotesis dilakukan untuk mengetahui ada tidaknya pengaruh tingkat bunga terhadap nilai tukar rupiah terhadap dollar.

Agar lebih jelas desain penelitiannya digambarkan sebagai berikut :

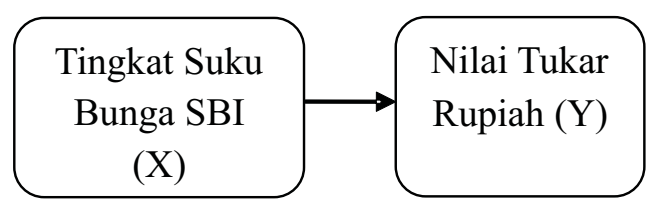

Gambar 1.2 Desain Penelitian

Dari gambar di atas dapat diketahui bahwa penelitian ini bertujuan untuk menguji pengaruh tingkat suku bunga SBI terhadap nilai tukar Rupiah. Variabel bebas (X) adalah variabel yang tidak dipengaruhi oleh variabel lainnya, dalam penelitian ini yaitu tingkat suku bunga SBI (X), yang secara parsial atau sendiri-sendiri berpengaruh terhadap variabel terikat $(\mathrm{Y})$ nilai tukar rupiah.

\section{Populasi, Sampel, dan Teknik Peng- ambilan Sampel}

\section{Populasi}

Menurut Sugiyono (2014: 119), populasi adalah "wilayah generalisasi yang terdiri atas: obyek/subyek yang mempunyai kualitas dan karakteristik tertentu yang ditetapkan oleh peneliti untuk dipelajari dan kemudian ditarik kesimpulannya". Populasi dalam penelitian ini adalah seluruh data time series per bulan tingkat suku bunga SBI dan nilai tukar Rupiah selama periode 2009-2015 yaitu sebanyak 84 data.

\section{Sampel}

Menurut Syofian Siregar, (2012: 145) "Sampel adalah suatu prosedur di mana hanya sebagian populasi saja yang diambil dan dipergunakan untuk menentukan sifat serta ciri yang dikehendaki dari suatu populasi". Sampel yang digunakan adalah nilai tukar (kurs) dan suku bunga SBI di Indonesia dengan periode pengamatan selama 7 tahun yaitu pada tahun 2009-2015 sehingga diperoleh sampel sebanyak 84 data.

\section{Teknik Pengambilan Sampel}

"Sampel adalah bagian dari jumlah dan karakteristik yang dimiliki oleh populasi tersebut" (Sugiyono, 2013: 149). Pengambilan sampel dilakukan dengan menggunakan metode sampling jenuh. "Metode sampling jenuh atau istilah lainnya sensus merupakan teknik penentuan sampel bila semua anggota populasi digunakan sebagai sampel" (Sugiyono, 2013:156).

\section{Teknik Pengumpulan Data}

Data-data yang diperlukan untuk penelitian dikumpulkan dengan teknik pengumpulan data. Dalam penelitian ini teknik pengumpulan data yang digunakan adalah:

a. Studi Kepustakaan

"Setiap penelitian memerlukan bahan yang bersumber dari perpustakaan. Bahan ini meliputi buku-buku, majalahmajalah, pamflet, dan bahan dokumenter lainnya" (Nasution, 2011: 145). 
b. Metode Dokumenter

"Metode dokumenter adalah metode yang digunakan untuk menelusuri data historis. Sebagian besar data yang tersedia adalah berbentuk, surat-surat, catatan harian, kenang-kenangan, laporan, dan sebagainya" (Burhan Bungin, 2005: 144).

Pengumpulan data dengan menggunakan studi kepustakaan serta dokumenter dilakukan dengan mengambil data dari situs www.bi.go.id.

\section{Instrumen Penelitian}

Instrumen penelitian yang digunakan dalam penelitian ini yaitu dengan menggunakan data time series dari website Bank Indonesia (www.bi.go.id).

Data time series adalah "sebuah kumpulan observasi terhadap nilai-nilai sebuah variabel dari beberapa periode waktu yang berbeda. Data seperti ini bisa dikumpulkan pada sebuah interval periode yang reguler seperti harian, mingguan, bulanan, kuartalan, tahunan, lima tahunan atau sepuluh tahunan" (Damodar N. Gujarati, 2010: 28). Data time series yang digunakan dalam penelitian ini menggunakan periode waktu bulanan.

\section{Teknik Analisis Data}

\section{Pengujian Asumsi Klasik}

Dalam menganalisis data menggunakan regresi linear sederhana. Syarat pendugaan model regresi linear sederhana yang baik adalah terpenuhinya tiga asumsi klasik. Uji asumsi klasik dalam penelitian ini menggunakan Uji Normalitas, Uji Autokorelasi, dan Uji Heteroskedastisitas.

a. Uji normalitas

"Uji Normalitas bertujuan untuk menguji apakah dalam model regresi variabel pengganggu atau residual memiliki distribusi normal" (Gozali, 2011:160). Menurut Ghozali (2011: 163) dasar pengambilan keputusan dalam uji normalitas adalah jika data menyebar di sekitar garis diagonal dan mengikuti arah garis diagonal atau grafik histogramnya menunjukkan pola distribusi normal, maka model regresi memenuhi asumsi normalitas.

b. Uji Autokorelasi

"Uji autokorelasi bertujuan untuk menguji apakah dalam model regresi linier ada korelasi antara kesalahan pengganggu (residual) pada periode $\mathrm{t}$ dengan kesalahan pengganggu pada periode t-1 (sebelumnya). Jika terjadi korelasi, maka dinamakan ada problem autokorelasi" (Imam Ghozali, 2011: 110). Menurut Damodar N. Gujarati (2007: 119) "uji yang paling terkenal untuk pendeteksian autokorelasi adalah uji statistik $d$ Durbin-Watson (DW test)". "Uji Durbin Watson (DW test) hanya digunakan untuk autokorelasi tingkat satu (first order autocorrelation) dan mensyaratkan adanya intercept (konstanta) dalam model regresi dan tidak ada variabel lag diantara variabel independen" (Imam Ghozali, 2011: 111).

c. Uji Heteroskedastisitas

Uji heteroskedastisitas bertujuan menguji apakah dalam sebuah model regresi, terjadi ketidaksamaan varian dari residual satu pengamatan ke pengamatan lainnya. Jika varian dari residual satu pengamatan ke pengamatan lain tetap, maka disebut homoskedastisitas dan jika berbeda disebut heteroskedastisitas. Model regresi yang baik adalah yang homoskesdatisitas atau tidak terjadi heteroskesdatisitas (Imam Ghozali, 2011: 139).

Pengujian asumsi klasik dimaksudkan untuk memastikan bahwa model yang diperoleh benar-benar memenuhi asumsi 
dasar dalam analisis regresi linear sederhana yang meliputi asumsi normalitas, tidak terjadi autokorelasi, tidak terjadi heteroskedastisitas dan tidak terjadi heteroskedastisitas.

\section{Pengujian Hipotesis}

a. Analisis Regresi Sederhana

Dalam penelitian pengaruh Tingkat Suku Bunga SBI terhadap Nilai Tukar Rupiah, analisis yang digunakan adalah dengan menggunakan regresi linier sederhana. Dimana hanya ada satu variabel $\mathrm{X}$ yang mempengaruhi satu variabel Y. Model regresi dalam penelitian ini sebagai berikut:

$$
\mathrm{Y}=\mathrm{a}+\mathrm{bX}
$$

Sumber: Sofyan Siregar (2014:379)

Mengingat besaran variabel berbeda-beda (nilai tukar USD/IDRrupiah dan tingkat suku bunga SBIpersen) dan mempunyai range yang lebar, maka dilakukan penyesuaian atau penyederhanaan terhadap data variabel-variabel tersebut. Dalam penelitian ini, penyesuaian dilakukan dengan mentransformasikan data dalam bentuk log natural (ln).

b. Uji $r^{2}$

Analisis koefisien determinasi $\left(\mathrm{r}^{2}\right)$ digunakan untuk mengetahui seberapa besar prosentase sumbangan pengaruh variabel independen secara serentak terhadap variabel dependen (Duwi Priyatno 2010: 66).

c. Ujit

Uji-t ini digunakan untuk mengetahui kebenaran pernyataan atau dugaan yang dihipotesiskan oleh si peneliti (Sofyan Siregar, 2012: 257).

\section{HASIL DAN PEMBAHASAN}

Deskripsi dari Tingkat Suku Bunga SBI, dengan jumlah data $(\mathrm{N})$ sebanyak 84 mempunyai deskripsi data sebagai berikut:
Ditinjau dari data pada website Bank Indonesia (www.bi.go.id) maka dapat diketahui bahwa tingkat suku bunga di Indonesia pada bulan Januari 2009 hingga bulan Desember 2015 cenderung mengalami kenaikan. Meski pada Januari 2009 memang mencapai titik tertinggi yaitu $8,75 \%$, tetapi seiring dengan adanya kebijakan pemerintah, tingkat suku bunga mengalami penurunan. Pada tahun 2010 suku bunga bertahan pada tingkat 6,50 dan terus menurun. Setelah bertahan di posisi 5,75\% sejak Februari 2012, suku bunga dinaikkan mulai Juni 2013. Pada bulan keenam Bank Indonesia menaikkan suku bunga menjadi $6,00 \%$.

Suku bunga acuan kembali dinaikkan menjadi $6,50 \%$. Kenaikan tersebut disebabkan imbas dari adanya tekanan inflasi serta pengaruh perekonomian global yang berujung pada tingginya tekanan mata uang domestik. Sedangkan nilai rata-rata (mean) variabel tingkat suku bunga selama tujuh tahun sebesar $6,79 \%$. Nilai standart deviasi pada tingkat suku bunga sebesar 0,73\%, hal ini menunjukkan bahwa standart deviasi masih dalam taraf normal karena tidak melebihi rata-rata tingkat suku bunga.

Deskripsi dari Nilai Tukar Rupiah, dengan jumlah data $(\mathrm{N})$ sebanyak 84 mempunyai deskripsi data sebagai berikut:

Ditinjau dari data pada website Bank Indonesia (www.bi.go.id) maka dapat diketahui bahwa nilai tukar rupiah di Indonesia pada bulan Januari 2009 hingga bulan Desember 2015 fluktuasi. Pada tahun 2009 Indonesia mengalami depresiasi karena Indonesia lebih banyak mengeluarkan mata uang untuk membeli satu unit mata uang negara asing dan pada tahun 2015 mengalami fluktuasi meski pada tahun tersebut mata uang Indonesia mengalami peningkatan. Rata-rata nilai tukar selama tujuh tahun mengalami depresiasi nilai tukar mata uang Januari-Juni 2009 dan 2011-2014, dan pada tahun 2015 mengalami apresiasi meski hanya 
640,72/USD. Nilai tukar tertinggi sebesar 14396,10 pada bulan September 2015, nilai tukar terendah sebesar 8532,00 pada bulan Agustus 2011, nilai rata-rata hitung (mean) sebesar 10481,73, sedangkan nilai standart deviasi pada nilai tukar rupiah sebesar 1627,92 .

\section{Hasil Uji Regresi}

Hasil perhitungan teknik analisis data dan uji hipotesis dengan menggunakan SPSS for Windows 22.0.

Hasil dari perhitungan Regresi Linier Sederhana di atas dapat dibuat persamaan garis regresi sebagai berikut : $\mathrm{Y}=3,169+$ 1,021X. Artinya koefisien ini menunjukkan bahwa tingkat suku bunga memiliki hubungan yang positif terhadap nilai tukar Rupiah. Hal ini berarti, apabila tingkat suku bunga mengalami peningkatan $1 \%$, maka nilai tukar Rupiah akan meningkat sebesar 1,021, apabila faktor lain dianggap tetap. Begitu pun sebaliknya, apabila tingkat suku bunga mengalami penurunan $1 \%$. Maka akan menyebabkan nilai tukar Rupiah juga menurun sebesar 1,021.

\section{Hasil Uji $\mathbf{r}^{2}$}

Nilai koefisien determinasi $\left(r^{2}\right)$ pada Tabel di atas diperoleh hasil sebesar 0,537. Artinya bahwa 53,7\% variabel nilai tukar Rupiah dipengaruhi oleh variabel bebasnya, yaitu tingkat suku bunga (X). Sedangkan sisanya 46,3\% variabel nilai tukar Rupiah dipengaruhi oleh variabel-variabel yang lain yang tidak dibahas dalam penelitian ini. Nilai korelasi ini menunjukkan bahwa hubungan antara variabel bebas dengan variabel terikat termasuk dalam kategori lemah karena berada pada cukup 0,50 - 0,69 berdasarkan ketentuan Pearson.

\section{Hasil Uji t}

Dari hasil perhitungan uji $\mathrm{t}$ diperoleh nilai $t_{\text {hitung }}$ sebesar 9,745 sedangkan nilai $t_{\text {tabel }}$ dengan jumlah responden 84 dan probabilitas 0,05 sebesar sebesar 1,989 . Hal ini berarti $t_{\text {hitung }}$ $\geq t_{\text {tabel }}(9,745 \geq 1,989)$. Sehingga dari hasil uji $\mathrm{t}$ di atas dapat disimpulkan bahwa Ha diterima, Ho ditolak, artinya bahwa ada pengaruh antara Tingkat Suku Bunga SBI Terhadap Nilai Tukar Rupiah Studi Pada Bank Indonesia.

\section{PENUTUP \\ Simpulan}

Berdasarkan hasil analisis data pada pembahasan bab sebelumnya, maka dapat diambil kesimpulan sebagai berikut:

1. Variabel tingkat suku bunga SBI memiliki pengaruh sebesar $53,7 \%$ terhadap nilai tukar Rupiah. Hal ini ditunjukkan oleh pengujian koefisien determinasi $\left(\mathrm{r}^{2}\right)$ yang memiliki hasil sebesar 0,537. Sedangkan sisanya sebesar 0,463 atau $46,3 \%$ perubahan nilai tukar dipengaruhi oleh variabel lain yang tidak dimasukkan pada penelitian ini.

2. Tingkat suku bunga SBI secara parsial berpengaruh signifikan terhadap nilai tukar Rupiah pada studi Bank Indonesia

a. Uji Regresi, yaitu Y=3,169+1,021X. Artinya koefisien ini menunjukkan bahwa tingkat suku bunga memiliki hubungan yang positif terhadap nilai tukar Rupiah. Hal ini berarti, apabila tingkat suku bunga mengalami peningkatan 1\%, maka nilai tukar Rupiah akan meningkat sebesar 1,021. Begitu pun sebaliknya, apabila tingkat suku bunga mengalami penurunan 1\%. Maka akan menyebabkan nilai tukar Rupiah juga menurun sebesar 1,021.

b. Uji t, yaitu $T_{\text {hitung }}$ sebesar 9,745, sedangkan $T_{\text {tabel }}$ sebesar 1,989. Hal ini berarti $T_{\text {hitung }} \geq T_{\text {tabel }}(9,745 \geq 1,989)$. Artinya ada pengaruh antara Tingkat Suku Bunga SBI terhadap Nilai Tukar Rupiah Pada Studi Bank Indonesia. 
Berdasarkan penelitian yang dilakukan, dapat diinterprestasikan bahwa apabila pemerintah lebih bijak ketika dalam mengatur tingkat suku bunga maka akan dapat meningkatkan nilai tukar Rupiah (apresiasi).

\section{Saran}

Berdasarkan kesimpulan di atas, maka dapat dikemukakan beberapa saran yang diharapkan dapat bagi Bagi Indonesia ataupun bagi pihak-pihak lain. Adapun saransaran yang diberikan antara lain:

1. Sebagai Bank Sentral, Bank Indonesia diharapkan dapat lebih bijaksana dalam mengambil dan mengeluarkan kebijakan di bidang moneter sehingga tujuan utama dari Bank Indonesia yaitu mencapai dan memelihara kestabilan nilai Rupiah dapat tercapai demi meningkatnya pertumbuhan ekonomi di Indonesia.

2. Pemerintah diharapkan tetap memperhatikan kebijakan yang terkait dalam pengendalian suku bunga SBI untuk dapat mendorong stabilitas pada nilai tukar Rupiah dan lebih memperhatikan lagi perhatiannya atas kondisi perekonomian sehingga krisis ekonomi tidak terjadi kembali.

3. Bagi peneliti yang tertarik ingin melakukan penelitian selanjutnya khususnya tentang pengaruh tingkat bunga SBI terhadap nilai tukar rupiah terhadap dollar, peneliti dapat menambah variabel di luar variabel tingkat suku bunga SBI yang merupakan variabel pendukung. Misalnya adalah variabel pertumbuhan ekonomi, pendapatan nasional, inflasi. Agar memperoleh hasil yang lebih bervariatif yang dapat menggambarkan hal-hal apa saja yang dapat berpengaruh terhadap nilai tukar rupiah.

\section{DAFTAR PUSTAKA}

Boediono. 2013. Ekonomi Internasional. Yogyakarta: BPFEE.

Bungin, Burhan. 2005. Metode Penelitian Kuantitatif. Jakarta: Kencana.

Darmadi, Hamid. 2013. Metode Penelitian Pendidikan dan Sosial. Bandung: Alfabeta.

Darmawi, Herman. 2006. Pasar Finansial dan Lembaga-Lembaga Finansial. Jakarta: Bumi Aksara.

Faisal, M. 2001. Manajemen Keuangan Internasional. Jakarta: Salemba Empat.

Ghozali, Imam. 2011. Aplikasi Analisis Multivariate dengan Program IBM SPSS 19. Semarang: Badan Penerbit Universitas Diponegoro.

Gujarati, N. Damodar. 2007. Dasar-dasar Ekonometrika. Jakarta: Erlangga.

Gujarati, N. Damodar. 2010. Dasar-dasar Ekonometrika. Jakarta: Salemba.

Joesoef, Jose Rizal. 2008. Pasar Uang dan Pasar Valuta Asing. Jakarta : Salemba Empat.

Kasmir. 2011. Bank dan Lembaga Keuangan Lainnya. Jakarta: Rajawali Pers.

Khajjah, Minkhatul. 2015. Pengaruh Inflasi dan Suku Nunga SBI Terhadap Nilai Tukar(US\$/Rp) Periode 2011-2013.

Madura, Jeff. 2006. International Corporate Finance. Jakarta: Salemba Empat. 
Mankiw, Gregory N. 2006. Pengantar Ekonomi Makro. Jakarta: Salemba Empat.

Martono dan Harjito. 2007. Manajemen Keuangan. Yogyakarta: EKONISIA.

Mishkin, Frederic S. 2008. Ekonomi, Uang, Perbankan dan Pasar Keuangan. Edisi 8. Buku 2. Jakarta: Salemba Empat.

Murni, Asfia. 2006. Ekonomika Makro. Bandung: Refika Aditama.

Nasution. 2011. Metode Research (Penelitian Ilmiah). Jakarta: Bumi Aksara.

Nazir, Moh. 2011. Metode Penelitian. Bogor: Ghalia Indonesia.

Noor, Juliansyah. 2011. Metode Penelitian. Jakarta: Kencana.

Priyatno, D. 2010. Paham Analisa Statistik Data dengan SPSS. Yogyakarta: Mediakom.

Puspitaningrum, Roshinta. Suhadak. dan Zahroh Z.A. 2014. Pengaruh Tingkat Inflasi, Tingkat Suku Bunga SBI, dan Pertumbuhan Ekonomi terhadap Nilai Tukar Rupiah Studi Pada Bank Indonesia Periode Tahun 2003-2012. Jurnal Administrasi Bisnis (JAB), Vol. 8, No. 1.

Sartono, Agus. 2001. Manajemen Keuangan: Teori dan Aplikasi. Yogyakarta: BPFE.

Siamat, Dahlan. 2004. Manajemen Lembaga Keuangan. Jakarta: Lembaga Penerbit Fakultas Ekonomi Univesitas Indonesia.
Siamat, Dahlan. 2005. Manajemen Lembaga Keuangan: Kebijakan Moneter dan Perbankan. Edisi Kelima. Jakarta: Lembaga Penerbit Fakultas Ekonomi Univesitas Indonesia.

Siregar, Syofian. 2012. Statistika Deskriptif untuk Penelitian: Dilengkapi Perhitungan Manual dan Aplikasi SPSS Versi 17. Jakarta: Rajawali Pers.

Siregar, Syofian. 2014. Statistik Parametrik untuk Penelitian Kuantitatif: Dilengkapi Perhitungan Manual dan Aplikasi SPSS Versi 17. Jakarta: Bumi Aksara.

Sugiyono, DR. 2013. Metode Penelitian Manajemen. Bandung: Alfabeta.

Sugiyono. 2013. Metode Penelitian Manajemen. Bandung: Alfabeta.

Sugiyono. 2014. Metode Penelitian Kombinasi (Mixed Methods). Bandung: Alfabeta.

Sukirno, Sadono. 2014. Makro Ekonomi Teori Pengantar. Jakarta: Rajawali Pers.

Suliyanto. 2011. Ekonometrika Terapan: Teori dan Aplikasi dengan SPSS. Yogyakarta: Andi Offset.

Sunariyah. 2004. Pengantar Pengetahuan Pasar Modal. Edisi Keempat. Yogyakarta: UPP STIM YKPN.

Taswan. 2010. Manajemen Perbankan: Konsep, Teknik \& Aplikasi. Yogyakarta: UPP STIM YKPN. 